\title{
The Theatre in Language Learning (TiLL) Model
}

\author{
Exploring Theatre as Pedagogy in the L2 Environment
}

\section{Sean Aita}

\begin{abstract}
This article presents an outline of the Theatre in Language Learning (TiLL) model for second language learners, pioneered since 1966 by Vienna's English Theatre in partnership with the Austrian Bundesministerium für Unterricht, Kunst und Kultur (BMUKK), linking text study, classroom based role play and professional performance with preshow and in-performance student interaction. It offers a reflection on the dramaturgy and practice of the Englisches Theater geht in die Schulen programme and explores how the model may impact upon student motivation in light of Ema Ushioda's qualitative research in this field. The article is written from the perspective of a professional theatre practitioner reflecting on the context of theatre as pedagogy within an L2 environment.
\end{abstract}

\section{Introduction}

In the words of Antonin Artaud, "To break through language in order to touch life, is to create or recreate the theatre" (Artaud 1958: 31). I reflect on this maxim whilst walking into the hall of a rural Hauptschule in the depths of winter. I am in Austria to watch a performance of my play A Perfect Match (Aita 2008), a 60 minute comedy drama in English for twelve- to fourteen-year-old school students. I am greeted by the sight and sound of hundreds of teenagers dragging the chairs from their classrooms into the hall, which has been transformed for this occasion into a theatre by the addition of a rostra stage and scenic flats and props which the actors have brought with them. As I watch the students form themselves into an audience I am aware that this scene is being repeated in hundreds of schools and theatres across the world. Annually approximately one million L2 learners on three continents ${ }^{1}$ attend performances by theatre companies producing plays which support the study of second languages. I

\footnotetext{
${ }^{1}$ Figures based on combined annual attendance from Vienna's English Theatre, White Horse and American Drama Group Europe 2007/08. Vienna's English Theatre approx. 350,000, White Horse approx. 350,000, American Drama Group Europe approx. 300,000. These numbers do not include estimates for other companies working in the field so actual totals may therefore be assumed to be higher. As yet no reliable combined figures for this sector have been compiled.
} 
cannot imagine that when he was writing The Theatre and its Double, Artaud (1958) could have pictured this scenario as he was, of course, referring to a form of gestural theatre which transcends linguistics. Yet paradoxically, a theatrical event for students studying a second language, in which the key focus is the spoken word, also manages to hold Artaud's vision at the centre of its methodology. If, as Martin Esslin says, "All dramatic performance is basically iconic, a direct visual and aural sign of a fictional or otherwise reproduced reality" (Esslin 1988: 43), then it follows that performing for an audience within the L2 learning environment where levels of language comprehension vary will undoubtedly require actors to transcend the medium of language and communicate directly through the use of inflection, gesture, and facial expression. The multiplicity of communication tools available to the actor in live performance is one of the key strengths of a theatrical approach, particularly with regard to the less able student. Yet in spite of the evident success of this methodology demonstrated by its continued growth and by the breadth of its application, and although there is an ample evidence base for the use of theatre, and drama, as an educational tool, there has been, as yet, comparatively little published academic research into, or analysis of, this specific model of language acquisition (see Fitzgibbon 1993; Brackley 1993; Schewe \& Shaw 1993) .

In an attempt to redress this balance I will present in this article an outline of what I will refer to as the Theatre in Language Learning Model (TiLL). This model, a sub-section of Theatre in Education with a specific focus on second language learning, was first trialed by Vienna's English Theatre and its educational partners in $1966,{ }^{2}$ and has been delivered by them through the Englisches Theater geht in die Schulen programme since 1970. The TiLL model has subsequently been adopted and developed by companies such as White Horse Theatre Company, The American Drama Group Europe, Il Palchetto Stage and the European Theatre Company. ${ }^{3}$ I am neither a linguist nor a teacher but a theatre practitioner with over twenty five years of experience in acting, writing and directing for L2 students. This article is based on an experiential interpretation of the work I have undertaken in writing and directing productions for twelve- to fourteen-year-old Austrian students who study English as a second language. I have applied a qualitative methodology throughout this paper which "values the subjective experience, self-determination and interdependency of all participants" (Yotis 2006: 196). I will also attempt to contextualize the theory underpinning the model's practice, and reflect on the ways in which it

\footnotetext{
${ }^{2}$ For a detailed history of this groundbreaking theatre company see Shafranek (2001) or the Vienna's English Theatre website. Available at: www.englishtheatre.at.

${ }^{3}$ American Drama Group Europe is a production company originally specializing in bringing productions in English and French to theatres throughout Europe and more recently worldwide. Available at: http://www.adg-europe.com. The European Theatre Company primarily produces work in French, German and Spanish, touring to schools in England. Available at: http://www.europeantheatre.co.uk. Il Palchetto Stage is an Italian producer importing and producing productions in English. Available at: http://www.palchetto.it/ipod/index.html. White Horse Theatre Company is a theatre in education company, performing in English and based in Germany. Available at: http://www.whitehorse.de.
} 
may impact upon L2 student motivation in light of Ema Ushioda's qualitative research in this field (Ushioda 2001).

\section{Context: Theatre in Education}

The conceptual framework of Theatre in Education (TIE) was established in Britain by Bertha Waddell in 1937, when she was given permission by Glasgow's Director of Education to take performances into primary schools. TIE was subsequently developed by practitioners such as Brian Way who "stated formally that the second of the three aims of his company was to assist teachers in all types of schools with methods of approach to drama in education." 4 This approach was strengthened immeasurably in the late 1960's by the publication of the Plowden Report for the Central Advisory Council for Education in England, strongly influenced by the work of developmental theorist Jean Piaget and his focus on child-centred learning. The report emphasized new approaches to learning, and provided the platform for the further development of the concept of using dramatic performance as an educational tool. This led to the foundation of the first full-time professional TIE company, at the Belgrade Theatre Coventry, in $1965 .{ }^{5}$ TIE has subsequently spread throughout the world. The 2000 conference of the International Centre for Theatre-in-Education ICTIE an initiative of the United Kingdom's Standing Conference of Young People's Theatre, held in Jordan, hosted practitioners from over 23 nations (cf. Attell 2002). Research demonstrates the effectiveness of this practice in teaching and learning particularly within the field of personal and social health education, and social exclusion (Blakey et al. 1991; Perry et al. 2002), and there is also evidence to suggest that TIE "has the potential to, but does not always, influence young people's attitudes" (Sykes 2005: 4).

\section{Student Motivation}

According to John Keller, "motivation is the neglected heart of our understanding of how to design instruction" (quoted in Thansoulas 2008: 1). One of the most important objectives of the TiLL model is to increase the motivation of students to learn, and maintain interest in a second language. This belief is shared by Peter Griffiths, Artistic Director of White Horse Theatre Company, who asserts that

\footnotetext{
${ }^{4}$ Cited in Attel, L. (2002: 2) The utilization of theatre in education for social development changes. Lecture. Children and the city conference. Jordan. 11/10/ 02. (internet) Araburban. Available at http://www.araburban.org/ChildCity/Papers/English/LinaAttel.pdf. Accessed: 1/12/08.

${ }^{5}$ As Attel points out this may have been the first professional company, but this practice had been trialed conceptually since the late 1930's. The first production at the Belgrade was called Pow Wow and involved a native American who was trapped by a 'cowboy.' The young audience had to decide whether or not to free him.
} 
[t]he plays boost pupils' motivation by letting them discover that they can enjoy an hour of English, and strengthen their confidence as they experience English as a means of communication rather than as a dry classroom exercise. ${ }^{6}$

Although it is beyond the scope of this article to present a full literature review and analysis of the wide range of motivational theories applied to the L2 learning environment, ${ }^{7}$ it is important to mention the contributions of social psychologists Gardner \& Lambert (cited in Ushodia 1999: 19f), who shaped the social- psychological and social-educational theories of student motivation. Though their studies are described by Ushioda as yielding "few genuinely useful insights for teachers and learners" (ibid.), their concept of integrative motivation characterized by a positive attitude towards the speakers and culture of the target language is important to the TiLL model. Since the 1990s there has been a radical re-orientation of this approach to motivational study with an increased emphasis on cognitive and affective models which place greater emphasis on learning styles. ${ }^{8}$ This change in focus was led in 1991 by what Ushioda refers to as the "call for a more practitioner validated, classroom based, concept" (ibid.) causing a wave of academic reaction (for a review see Dörnyei 1998). One of the most important elements to emerge from this reorientation of approach in relation to the TiLL model is the concept of intrinsic and extrinsic motivation. Intrinsic motivation is the desire to do something as an end in itself, whilst extrinsic motivation is doing something for a separable outcome (a qualification, or job). Intrinsic motivation is generally considered the "optimal form" where motivation comes "from within" (Deci \& Flaste 1996, quoted in Usioda 1999: 21). This form of motivation is "founded in deep-rooted personal interests and positive attitudes and feelings" (Ushioda 1991: 21), and can be related to a student's experience, and appreciation, of other cultures. In one of the first attempts to create a qualitative research paradigm for the motivational study of language acquisition, Ushioda identifies eight descriptive dimensions for the analysis of L2 learner motivation (Ushodia 2001: 102).

\section{Academic interest}

2. Language related enjoyment/liking

3. Desired levels of L2 competence

4. Personal goals

\section{Positive learning history}

\footnotetext{
${ }^{6}$ White Horse Theatre website. Available at: http://www. whitehorse. de.

${ }^{7}$ Some of the most comprehensive research into motivation in recent years has been undertaken by Dörnyei et al. (Dörnyei \& Ushioda 2009; Dörnyei \& Schmidt 2001)

${ }^{8}$ For a detailed review of motivational theories see Curtis Kelly's online article A Review of Traditional and Current Theories of Motivation in ESL. Available at: http://www.osaka-gu.ac. jp/php/kelly/papers/motivation.html. Accessed 02/01/09.
} 
6. Personal satisfaction

7. Feelings about French speaking countries or people

8. Eternal pressures/ incentives

For the purposes of this article I shall refer to the two dimensions which appear to have most relevance to the TiLL model: (2.) Language related enjoyment/liking and (7.) Feelings about (English) $)^{9}$ speaking countries or people.

\section{The TiLL Model}

The TiLL model is an applied theatre model ${ }^{10}$ which was created by the founder of Vienna's English Theatre, Austrian Theatre Director, Dr Franz Shafranek and his wife, American actress Ruth Brinkmann. In 1970, in partnership with Leo Leitner, Head of Secondary Schools at the Austrian Ministry of Education and Culture (BMUKK), they jointly devised a programme of educational theatre under the title Englisches Theater geht in die Schulen.

The core objective of the model was to produce theatrical productions supporting the study of English as a foreign language ${ }^{11}$ by offering:

- Professional theatre performances, acted by native English speakers;

- The commission of age-appropriate and specifically targeted plays;

- The publication and distribution of the play texts to students prior to performance;

- The provision of educational support materials (exercises and questions based on the productions and texts).

The key pedagogical outcomes of this model were defined as: ${ }^{12}$

- Building cross-cultural understanding;

- Making the study of English "fun";

- Taking language study out of the classroom context;

- Hearing English spoken by native speakers;

\footnotetext{
${ }^{9}$ Ushioda's research was into students studying French. I have substituted English here for reasons of clarity.

${ }^{10}$ Applied theatre is the term given to the use of drama or theatre in community, educational and social welfare settings within the discipline of performance studies.

11 The model has subsequently been used for students of French, Spanish and German.

12 The aims and objectives of the model were never formally recorded. They were described to me in 1984 by Nicholas Allen when I was first employed as an actor at Vienna's English Theatre.
} 
- Providing opportunities for conversations with native speakers.

The TiLL model was, and still remains, based on three key principles: reading, seeing and hearing. ${ }^{13}$

The script of a selected play is read in the classroom and all its ramifications are discussed in detail. The students are familiarized with the plot, characters and the medium of a foreign language. The direct experience of the scenes is enhanced through understanding, the action in the play forms a kind of unity between actors and spectators, and theatre becomes inter-action. (Shafranek 2001: 102)

Students are supplied with a copy of the selected text, (ideally) to be studied in the classroom prior to a performance of the play. Performances are undertaken by a team of professional native speaking actors and take place within the school itself or in a theatre location nearby. The tripartite focus of reading, seeing and hearing particularly supports three of the distinct learning styles identified within Fleming's celebrated VARK model $;{ }^{14}$ the visual, the auditory and the read/write. It also has the potential to contain the kinesthetic within the reading category, and in audience participation, as will be demonstrated.

Nicholas Allen, Director of Schools Touring at Vienna's English Theatre throughout the 1970's and 1980's, describes putting teachers at the front of the formative process in selecting the type of plays to be performed. To begin with, regular conferences with teachers were held on an informal basis. In 1985, these led to the formation of a group of approximately thirty teacher-organizers whose input helped shape the development of the programme's dramaturgy and practice. ${ }^{15}$ This initial consultation led to the implementation of the first of the two dramaturgical formats which have dominated the TiLL model since its inception; the adaptation of classical texts such as Oscar Wilde's The Canterville Ghost, and Mark Twain's Huckleberry Finn. This format is now less prevalent, particularly in work created for younger learners, due to changes in thinking about social and cultural identity within the L2 classroom. The second format to be developed was based upon the creation of issue-led ${ }^{16}$ contemporary drama.

\footnotetext{
13 A process described by Leo Leitner quoted in Shafranek, J. (ed.) (2001: 102f) Vienna's English Theatre: Against All Odds. Vienna. Deuticke. The reading category is not universally applied by all of the companies mentioned in this paper delivering versions of the TiLL model, though all produce teaching materials linked to the productions.

14 The VARK system is an educational theory which identifies learning styles students can be tested against. This system is in wide use by British universities and teaching methods are adjusted to match the identified learning style of the student. For further information see Fleming, N. VARK: A Guide to Learning Styles. Available at: http://www.vark-learn.com/ english/index.asp. Accessed 23/11/08.

15 Allen, Nicolas. Telephone conversation 30/11/08.

16 Issue-led or issue-driven are terms taken from Performance Studies. They are applied to drama which takes a particular social or political issue as its primary focus (similar to the concept of the "problem" play in the nineteenth century). It is often contrasted with characterled or character-driven drama.
} 


\subsection{Reading}

Engagement in the process of reading the plays is potentially both active and passive. Students can read to themselves at home exploring vocabulary independently from the class structure, a learning strategy favored by students who are "shy and introverted" (Ghani 2003: 31) who prefer to learn a second language through "grammar drills and sentence analysis" (ibid.). In the active form (reading aloud) students and teachers can identify practical outcomes such as fluency, pronunciation, and engagement with emotional or social context. Teachers are encouraged by Vienna's English Theatre to engage their students in role-play activities based on characters or situations, and to act out sections of the text ${ }^{17}$ which is sub-divided into short titled scenes for ease of navigation. ${ }^{18}$

In his internet article on the Use of Drama in the Classroom on the Teaching English website, Robinson cites Maley \& Duff (1978) and Wessels (1987) as authors who have demonstrated the core values of this methodology; in that it can "overcome the students' resistance to learning the new language by making the learning of the new language an enjoyable experience"19, a particularly important outcome in a compulsory learning setting. Robinson also highlights the research undertaken by Collie \& Slater into the positive contributions made to language learning by the study of literature. Primary texts constitute "valuable authentic material" which "expose learners to different registers" (Collie \& Slater 1987: 3). There is also strong evidence that reading produces superior vocabulary retention rates in L2 learners, in comparison with the use of vocabulary lists (cf. Hermann 2003: 1). Although the intention is for the process to be linear (for the students to read first then see and hear) the application of the model is non-prescriptive allowing teachers to apply it in the way they feel works best for them, or their students.

As they move towards adulthood young people become particularly keen to engage with and explore social, ethical and moral questions. ${ }^{20}$ To reflect this interest the contemporary drama strand includes relevant contemporary issues to provide the potential for debate, and impact upon personal experience. This approach has produced work exploring gender, substance abuse, race, consumer culture, anorexia, bullying and teenage pregnancy. Plays have interrogated the effects of new technology, and changes in social behavior on teenagers. In Hotmail from Helsinki author Judy Upton (2001) questions the effects of online social networking on inter-personal relationships, whilst in Virtual Heroes, Clive Duncan (2007) explores the notion of the computer

\footnotetext{
17 For a full and detailed analysis of the benefits of "student affect and character creation using drama" in an L2 setting see Sosulski (2008).

18 This process encouraged Carina, an Austrian student who attended a performance of Virtual Heroes (Duncan 2007) to write that she had enjoyed the show, but that their own performance was better! See appendix student letters $(\mathrm{h})$.

${ }^{19}$ Cited in Robinson, H.: Teaching English. Using Drama Texts in the Classroom. Available at: http://www.teachingenglish.org.uk/think/articles/using-drama-texts-classroom.

${ }^{20}$ I have observed this tendency frequently in the choices teenage students of acting make when asked to create improvised dramatic scenarios.
} 
avatars and their use as transference mechanisms. According to a student in Perg, "the pupils liked this topic, because using email, chat-rooms and playing games on the computer are already common ways of communication and entertainment for them." ${ }^{21}$ As Helene Hirsch, former chair of the Teachers of English in Austria Association, says in the introduction to Claudia Leaf's Little Girl Lies, which tackles teenage sexuality, "this play" (and by implication, this form of drama) "explores eminently personal and emotional issues [and] decisions about the future" (Leaf 2008: 2). The interrogation of contemporary social and cultural issues provides a platform for students to personalize their learning. The content of the material being studied can be related to their own experience helping inform their understanding of the normative practices and cultural orthodoxy, or heterodoxy within the target linguistic area. Alongside the dramaturgical focus on issues there are three other key elements which have been developed.

- Role models: to encourage personal identification and empathetic response.

The importance of role identification in the development of personal aspiration and motivational goals is well known; ${ }^{22}$ within the educational arena it can help the student to "personalize interests, visualize goals, and learn through experiences" (Arth \& Burnett 2001: 1). Vienna's English Theatre has consciously applied this by commissioning works in which the central characters are young people, and often young people who are encountering parental or social boundaries, managing to navigate their way, generally successfully, through these negotiations.

- Comedy: to bring the potential for laughter into the classroom and to build actor / audience rapport during performance.

The majority of feedback received by Vienna's English Theatre refers specifically to student appreciation of the comedy elements in the productions (see appendix, student letters). ${ }^{23}$ In her paper The Value of Laughter in the Language Classroom Bostina-Bratu (2006) cites Provine's contention that "laughter is not primarily about humour, but about social relationships." She believes that it can also contribute to class unity and learning, and goes on to suggest that "reading or studying a comedy may please students more than reading a tragedy, or literature covering other aspects of daily life." ${ }^{24}$ Comedy is widely applied as

\footnotetext{
${ }^{21}$ Perg HS website. Virtual Heroes. Available at: http://hs2.perg.at/index.aspx?url= http://hs2.perg.at/beitraege/zeigeBeitragEinzeln.aspx?beitragNr=2008216103324971. Accessed 2/12/08.

22 One has only to think of Barack Obama's impact on perceptions of democracy and the career potential of minority ethnic American citizens to recognize its power.

${ }^{23}$ In the words of thirteen year old student Alex, "the theatre was very funny and I laughed very much." See appendix, student letters (k).

${ }^{24}$ Bostina-Bratu, S. (2006: 4) The Value of Laughter in the Language Classroom. Available at: http://www . armyacademy .ro/biblioteca/anuare/2007/a30.pdf. Accessed 30/11/08.
} 
a performance technique by directors of companies applying the TiLL model, all of whom have a conscious or unconscious awareness of its ability to reduce anxiety in both actor and audience creating a linking social dynamic, and building a sense of us. In fact the process may even literally make the audience feel better disposed towards the actors/performance by increasing endorphin levels within their brains (cf. Berk et al. 2006: 62 ).

- Colloquial phrases: idiomatic expressions and slang words; to assist in the formation of an independent mental lexicon not subject to translation and to offer access to a vocabulary which may appeal specifically to younger people.

Plays commissioned by Vienna's English Theatre and others applying the TiLL model have included colloquialisms, idiomatic phrases and slang words such as pukesville, slimeball, don't get your knickers in a twist, misery-guts, ghetto-blaster, local yokel, get out of my face, wicked, sorted and flaky. ${ }^{25}$ Research into the effects of slang on L2 learners in high school and university has been undertaken by Charkova, who identified the younger participants as appreciating the knowledge of slang as "a way of group belonging and projecting an image of looking cool" (Charkova 2007: 369). Though it is debatable whether or not arming teenagers with a series of L2 pejoratives is entirely beneficial, the temptation to acquire genuine teen-speak for young learners may help in overcoming resistance to compulsory language learning, and build on motivational factors relating to Ushioda's descriptor 2. (Ushodia 2001: 102).

\subsection{Seeing, Hearing, and Interaction}

That a play is a blueprint for performance is self-evident. As Sosulski (2008) points out, such texts "only blossom into their full range of meaning when realized upon the stage by actors in flesh and blood." There is a wide range of available research into the semiotics, phenomenology and reception of dramatic performance (States 1985; Esslin 1988; Pavis and Williams 2003; Bennett 1997) exploring the way in which theatrical events can produce "powerful effects upon our lives, our thinking, our behaviour" (Esslin 1988: 2), and investigating the complex nature of the interaction between the iconic, deictic, symbolic, intentional and un-intentional signs produced by the actors in the presentation of a play and their ultimate reception and interpretation by an audience. ${ }^{26}$ The complexity of interpretation relating to making and viewing theatre is potentially increased by the TiLL model within this context. It seeks to present a cross-cultural representation of English life to an audience which does not share an L1 background with the actors. In reference to performances which "originate in or somehow reflect a culture other than one's own" (Bennett

\footnotetext{
25 Examples taken from A Perfect Match (Aita 2008) and Little Girl Lies (Leaf 2008).

${ }^{26}$ For a recent theory of production and reception see Bennett (2007).
} 
1997: viii), Bennett contends that it is "through such performances we can learn about our engagement, or not, with another's culture." 27 That the actor is at the centre of the performance process is axiomatic, and actors are often, by nature of their profession, outgoing people who can easily fascinate learners who often experience their every day learning environment as rather constraining. As Jon Whitmore says:

[e]very performer is unique: each possesses a personal style, charisma or élan. This special almost indefinable quality is heightened when a person transforms herself into a performer on stage before a live audience. (Whitmore 1994: 67)

Their potential influence on the provision of a positive experience of British culture and people, supporting Ushioda's (2001) motivational descriptor 7. for students attending performances using the TiLL model, cannot be overestimated. The Englisches Theater geht in die Schulen progamme has attempted to enhance this perceived effect by using:

- Preshow interaction: Personal contact with students and actors through conversation, framing process prior to performance;

- In performance interaction: The opportunity for some or all students to perform in, or otherwise engage kinesthetically with the performance.

Both activities were pioneered in the early 1970's by Director of Schools Touring Nicholas Allen and have undergone a series of changes and refinements ever since. Preshow interaction requires the actors to enter the audience space and speak directly to audience members as individuals, or in small groups either in-role, or as themselves. This has taken a number of forms in recent years. Actors either speak as themselves, or as part of what Esslin might refer to as 'a frame'28 using character-led interaction. Before performances of The Canterville Ghost (Wilde \& Allen 1995) the audience were welcomed into the theatre space, and treated as visitors by Lord Canterville to the Canterville Chase. They were then accosted by actors playing the younger members of the Otis family who were supposedly joining the tour with them. The inclusion of the audience within the theatrical scenario, implicit within this form of engagement, was described by Elinor Fuchs (1996) in her discussion of theatre as "shopping", as producing a "familiarization effect" which arises when the audience member is metaphorically "taken out of the theatre and invited to make herself at home" (cited in Kattwinkle 2003: 4). Vienna's English Theatre has applied a wide range of approaches to directing performance interaction

\footnotetext{
27 She actually says that it is not only through such performances.

28 Esslin, M. (1988, Chapter V) The Field of Drama: How the Signs of Drama Create Meaning on Stage and Screen. London. Methuen. This chapter explores the way in which architecture, ambience, space, and elements which lift or create expectation in the viewer. I am using 'frame' in this context, of using pre-performance interaction as a method of developing and manipulating expectation of the event.
} 
since its inception as a practical methodology in 1983 when Nicholas Allen, drawing on influences from the music hall, vaudeville and folk music traditions included songs and musical scores within the play text. The students were subsequently taught these songs in class and invited to sing along with the actors during the performance. The popularity of this approach with teachers and pupils led to the development of a second modified form, drawing on British pantomime practice, in which members of the audience were invited onto the stage for formally devised interactive segments.

In performances of the play Bananas!, an exploration of consumer culture and diversity issues, Allen \& Aita (1999) included lines which were assigned to student performers who responded to their cues and acted within the context of the narrative. Writer Clive Duncan (2007) used translation skills as a focus for interaction in Virtual Heroes asking students to help the characters within the play to resolve a problem by coming onstage to translate a letter from German into English. Although not entirely conforming to Augusto Boal's concept of the 'spect-actor'29 (Boal \& Jackson 2002: 30), the direct engagement of students as participants on stage as part of the performance could instead be viewed as an example of pseudo-transgressive behaviour.. Victoria Turner discusses the effects of pseudo-transgressive behaviour on audiences in her paper theorizing British pantomime tradition Oh no it isn't! Audience participation and community identity stating that,

[...] transgression within the safety of defined boundaries leads to normative communitas, the audience is returned to life having experienced a transformation for a limited time and place, within safe boundaries. (quoted in Taylor 2008: 1)

It also appears that those who do not physically cross the boundary from auditorium to stage can also share in the thrill of this validated form of transgressive behaviour. ${ }^{30}$ The belief that direct engagement with the audience is essential to the TiLL model is not only held by Vienna's English Theatre. Paul Stebbings, Artistic Director of TNT theatre, ${ }^{31}$ a company working in partnership with the American Drama Group Europe, refers to the importance of an "audiencentric" approach.

The relationship essential in our theatre is not between actor and text, or actor and actor, or actor and director, or even designer and director but actor

\footnotetext{
29 Theatre practitioner and educator Augusto Boal developed the concept of the spect-actor through his work on forum theatre. The true spect-actor is an audience member who takes on a role within a dramatic scenario in order to change its outcome. Contained within Boal's concept there is a very strong sense of analysis and transformation, where the audience resolves issues rather than simply accepting them.

30 Student Melissa from Feldkirch comments in a letter to Vienna's English Theatre that she "found it very exciting that (her friend) Sandra was onstage" during the production of Virtual Heroes. See appendix, student letters (e).

${ }^{31}$ TNT is a company based in the United Kingdom, directed by Paul Stebbings, who works closely with the American Drama Group Europe producing touring productions in English and French. See Amercian Drama Group Europe. Available at: http://www.adg-europe.com. Accessed 28/11/08.
} 
and audience. ${ }^{32}$

\section{Conclusion}

That the TiLL model has survived so long, and not only survived but prospered and spread $^{33}$, is evidence that its perceived value within the L2 learning environment is high. Teachers, schools, and educational institutions have all supported this practice over the past forty years by offering financial subsidy, continuing to book performances, and by studying the plays produced by the companies in the classroom. It is interesting therefore to reflect on the fact that this paper is the first attempt to formally recognize, and name, the TiLL model. I believe that I have demonstrated evidence to support the contention that this model affects the motivational factors (2. and 7.) identified in Ushioda's research, which may be an important factor in explaining why the model has been disseminated so widely.

Considering the levels of participation and the longevity of this methodology, it seems surprising that so little interrogation of the practice has been undertaken academically thus far. Nonetheless, whilst writing this article, I realize that my colleagues and I have actually been engaged in a thirty year programme of action research, constantly ensuring that the model does not remain static but evolves to reflect changes in society, culture and linguistics. We had just never recognized that we were doing it.

\section{Bibliography}

Aita, Sean (2008): A Perfect Match. (pdf download) Vienna: Vienna's English Theatre / BMUKK

Aita, Sean / Allen, Nicholas (2000): Bananas! Vienna: Vienna's English Theatre / BMUKK

Artaud, Antonin (1958): The Theatre and Its Double. New York: Grove Press

Bennett, Susan (1997): Theatre Audiences: A Theory of Production and Reception. London: Routledge

Blakey, Virginia / Pullen, Elaine (1991): You Don't Have to Say You Love Me: An Evaluation of a Drama-based Sex Education Project for Schools. In: Health Education Journal 50/4, 161-165

Boal, Augusto / Jackson, Adrian (2002): Games for Actors and Non Actors. London: Routledge

\footnotetext{
32 Quotation from American Drama Group Europe website (see note 31 above) .

33 Using Vienna's English Theatre as an example, output rose from approximately sixty performances in the early 1970's to over three hundred by 1982, and by the early 1990's had reached current levels, in which four or five touring companies annually deliver performances to approximately 300,000 pupils.
} 
Brecht, Bertolt / Willett John (1974): On Theatre: The Development of an Aesthetic. London: Methuen

Collie, Joanne / Slater, Stephen (1987): Literature in the Language Classroom. Cambridge: Cambridge University Press

Coulmas, Florian (1989): Language Adaptation. Cambridge: Cambridge University Press

Dörnyei, Zoltan (1998): Motivation in Second and Foreign Language Teaching. In: Language Teaching 31, 117-135

Dörnyei, Zoltan / Schmidt, Richard (2001): Motivation and Second Language Acquisition. Manoa, HI: University of Hawaii Press

Dörnyei, Zoltan / Ushioda, Ema (2009): Motivation, Language Identity and the L2 Self. Bristol: Multilingual Matters.

Duncan, Clive (2007): Virtual Heroes. (pdf download) Vienna: Vienna's English Theatre / BMUKK

Esslin, Martin (1988): The Field of Drama: How the Signs of Drama Create Meaning on Stage and Screen. London: Methuen

Fuchs, Elinor (1996): The Death of Character: Perspectives on Theatre after Modernism. Bloomington: Indiana University Press

Ghani, Mamuna (2003): Language Learning Strategies Employed by L2 Learners. In: Pakistan Journal of Language 4/1, 31-36

Kattwinkel, Susan (2003): Audience Participation: Essays on Inclusion in Performance. Westport: Praeger

Leaf, Claudia (2008): Little Girl Lies. (pdf download) Vienna: Vienna's English Theatre / BMUKK

Macdonald, Robert / Marsh, Jane (2001): Disconnected Youth. In: Journal of Youth Studies 4/4, 375-391

Pavis, Patrice / Williams, David (2003): Analyzing Performance 2. Ann Arbor, MI: University of Michigan Press

Perry, Cheryl / Zauner, Marguerite / Oakes, Michael J / Taylor Gretchen / Bishop, Donald (2002): Evaluation of Theatre Production about Eating Behaviour of Children. In: Journal of School Health 72/6, 256-261

Pintrich, Paul / Schunk, Dale (1996): Motivation in Education: Theory, Research and Applications. Englewood Cliffs: NJ: Prentice-Hall

Plowden, Bridget (1967): Children and Their Primary Schools: A Report of the Central Advisory Council for Education, England. London: Her Majesty's Stationery Office

Shafranek, Julia (ed.) (2001): Vienna's English Theatre: Against All Odds. Vienna: Deuticke

Schewe, Manfred / Shaw, Peter (1993): Towards Drama as a Method in the Foreign Language Classroom. Frankfurt/M.: Peter Lang

States, Bert O. (1985): Great Reckonings in Little Rooms: On the Phenomenology of Theater. Berkeley: University of California Press 
Twain, Mark / Aita, Sean (adaptor) (1997): The Adventures of Huckleberry Finn. St Pölten: Gerstmayer

Upton, Judy (2001): Hotmail from Helsinki. Vienna: Vienna's English Theatre / BMUKK

Ushioda, Ema (1999): Motivation and Good Language Learners. In: Griffiths, Carol: Lessons from Good Language Learners. Cambridge: Cambridge University Press, 19-34

Ushioda, Ema (2001): Language Learning at University: Exploring the Role of Motivational Thinking. In: Dörnyei Zoltan; Schmidt Richard (eds): Motivation and Second Language Acquisition. Honolulu, HI: University of Hawaii Press, 93-125

Whitmore, Jon (1994): Directing Post-modern Theatre: Shaping Signification in Performance. Ann Arbor, MI: University of Michigan Press

Wilde, Oscar / Allen, Nicholas (adaptor) (1995): The Canterville Ghost. Graz: Universität Buchdruckerei

Yotis, Lambros (2006): A Review of Dramatherapy Research in Schizophrenia: Methodologies and Outcomes. In: Psychotherapy Research 16/2, 90-200

American Drama Group Europe website (no date). Available at: http://www. adg-europe.com. Accessed 28/11/08

Arth, Tona / Burnett Melissa (2001): The Importance of Role Models in the Career Development of Students. Lecture. AMA Fall Educators Conference. Available at: http://sbaer.uca.edu/research/mma/2001/40.pdf. Accessed 30/11/08

Attel, Lina (2002): The Utilization of Theatre in Education for Social Development Changes. Lecture. Children and the City Conference. Jordan. 11/10/ 02. Araburban. Available at: http://www.araburban.org/ChildCity/Papers/English/LinaAttel.pdf. Accessed: 1/12/08

Berk, Lee Tan / Stanley, Bittmann Barry / Westengard, James (2006): Modulation of Neuroimmune Parameters during the Eustress of Humor associated Mirthful Laughter. Available at:

http://www.worldlaughtertour.com/pdfs/Lee\%20Berk-\%20AltTher\%20Vol\%207-2.pdf. Accessed 28/11/08

Bostina-Bratu, Simona (2006): The Value of Laughter in the Language Classroom. Available at:

http://www . armyacademy .ro/biblioteca/anuare/2007/a30.pdf. Accessed 30/11/08

Charkova, Krassimira: A Language without Borders: English Slang and Bulgarian Learners of English Language. In: Language Learning57/3, 369-416) Ingenta Connect. Available at: http://www. ingentaconnect. $\mathrm{com} / \mathrm{content} / \mathrm{bpl} / \mathrm{lang} / 2007 / 00000057 / 00000003 /$ art00003. Accessed $19 / 10 / 08$ 
European Theatre Company website (no date) Available at:

http://www. europeantheatre.co.uk. Accessed 30/11/08

Fleming, Neil (no date): VARK: A Guide to Learning Styles. Available at:

http://www.vark-learn.com/english/index.asp. Accessed 23/11/08

Hermann, Frank (2003): Differential Effects of Reading and Memorization of Paired Associates on Vocabulary Acquisition in Adult Learners of English as a Second Language. In: TESL-EJ Teaching English as a Second or Foreign Language 7/1. Available from http://tesl-ej.org/ej25/a1.html. Accessed 4/11/08

Il Palchetto Stage website (no date). Available at: http://www.palchetto.it/ipod/index.html. Accessed 30/11/08

Kelly, Curtis (no date) A Review of Traditional and Current Theories of Motivation in ESL. Available from http://www.osaka-gu.ac.jp/php/kelly/papers/motivation.html. Accessed 02/01/09

Perg HS website (no date) Virtual Heroes. Available at: http://hs2.perg.at/index.aspx?url=http://hs2.perg.at/beitraege/ zeigeBeitragEinzeln.aspx?beitragNr=2008216103324971. Accessed 2/12/08

Peterson, Elizabeth / Coltrane, Bronwyn (2003): Culture in Second Language Teaching. In CAL Digest. 12/03. Available at:

http://www.cal.org/resources/Digest/0309peterson.html. Accessed 30/11/08

Robinson, Henry (no date): Teaching English. Using Drama Texts in the Classroom. Available at:

http://www.teachingenglish.org.uk/think/articles/using-dramatexts-classroom. Accessed 14/04/09

Sosulski, Michael J. (2008) Workshop in German Drama: Using Period Acting Techniques to Enhance Second Language Acquisition. In: Scenario: Journal for Drama and Theatre in Foreign and Second Language Education 1/08. Available at: http://epu.ucc.ie/scenario/2008/01/sosulski/02/en. Accessed: 10/11/08

St. Paul SG website (no date). Available at: www.stiftsgymstpaul.at/projekte/englisch/virtualheroes_2008/virtualheroes.htm. Accessed 30/11/08

Stebbings, Paul (no date) Amercian Drama Group Europe. Available at: http: / /www. adg-europe.com. Accessed 28/11/08

Sykes, Susie (2005) Review of Literature Relating to Theatre in Education as a Tool in Alcohol Education. Report for the Alcohol Education and Research Council. Available at:

http://www.aerc.org.uk/documents/pdfs/finalReports/AERC_FinalReport_0026.pdf. Accessed: 12/11/08 
Taylor, Millie: (2008) Oh No It Isn't: Audience Participation and Community Identity. In: Internet-Zeitschrift für Kulturwissenschaften: Zeichen, Texte, Kulturen. Konvivialität aus semiotischer Perspektive. Vol 1.2/15. 06/04. Available at: http://www.inst.at/trans/15Nr/01_2/taylor15.htm. Accessed $12 / 11 / 08$

Thanasoulas, Dimitrios (2008) Motivation and Motivating in the Foreign Language Classroom. In The Internet TESL Journal. xiv/10. Available at: http://iteslj.org/Articles/Thanasoulas-Motivation.html. Accessed: $12 / 11 / 08$

Vienna's English Theatre website (2008). Available at: http://www.englishtheatre.at. Accessed: 1/12/08

White Horse Theatre Company website (2008). Available at: http://www.whitehorse. de. Accessed 10/11/08

Texts

Internet Sources 


\section{A Student Letters}

Table 1: Sample of (un-edited) letters from 12-14 year old students sent in response to tour of Virtual Heroes by Clive Duncan. Vienna's English Theatre 2007.

\begin{tabular}{|c|c|}
\hline a. & $\begin{array}{l}\text { Dear actors I think your act Virtual Heroes was very funny, you played the story } \\
\text { very well. I hope you will come next year too. The contests was very easy to } \\
\text { understand. I think the man who played Aaron was the funniest. (Patrick) }\end{array}$ \\
\hline b. & $\begin{array}{l}\text { The play was very funny and lots of actions. It is the best that I have ever seen. } \\
\text { My favorites player in Kevin Millar (Killer Miller). The songs that they sings are } \\
\text { very funny. It was really good making. (David) }\end{array}$ \\
\hline c. & $\begin{array}{l}\text { Kevin is the funniest player because he always make jokes. Rita are also good, } \\
\text { she is a swot. Aaron was a very good and funny player. Sharon was made } \\
\text { jokes and she is very funny. (no name) }\end{array}$ \\
\hline d. & $\begin{array}{l}\text { I think it's funny. I think it shoes very good who is the normal live of two } \\
\text { teenagers. In a normal school. (Aaron) }\end{array}$ \\
\hline e. & $\begin{array}{l}\text { I found that the Sapphire's stone song was really good, end exciting. I found it } \\
\text { very exiting that Sandra must on the stage. It was very funny. (Melissa) }\end{array}$ \\
\hline f. & $\begin{array}{l}\text { The play was good and funny. It was the best play that I ever see. The players } \\
\text { were very good. Kevin Millar were good at all scene. He was funny! (Stefan) }\end{array}$ \\
\hline g. & $\begin{array}{l}\text { I find the story was really good. Sapphire sings very beautiful. Sapphire's } \\
\text { dress is nice and sexy. (Rabia) }\end{array}$ \\
\hline h. & $\begin{array}{l}\text { I liked the theatre very much. It was very good performed and the actors } \\
\text { played very good too. Once they said to two of the audience they should come } \\
\text { onto the stage, that was very funny: ) Before the theatre began George talked } \\
\text { to us. The could sing very good, but our version is better. haha. Rescue me } \\
\text { and l'll rescue you - sing. (Carina) }\end{array}$ \\
\hline i. & $\begin{array}{l}\text { I liked the theatre very much it was very funny, the actors played good and they } \\
\text { were very friendly. I liked that George was talking to us. He is a funny man. I } \\
\text { like you :) They could sing very good. Nice nice nice. ( Laura) }\end{array}$ \\
\hline j. & $\begin{array}{l}\text { Hello! My name is Vera. In your play I laughed the whole time because it was } \\
\text { so funny All things passed together and the set was great. The performance is } \\
\text { perfect. The song from Sapphire was really good. All in all it was always } \\
\text { interesting, exciting and I could understand all. (Vera) }\end{array}$ \\
\hline k. & $\begin{array}{l}\text { The theatre was very funny and I laughed very much. The stage was very } \\
\text { small but you made it very good. I hope you will be performancing theatres like } \\
\text { this on again. So that all the people can see such a funny theatre. You made it } \\
\text { super. (Alex) }\end{array}$ \\
\hline
\end{tabular}

